\title{
Research on the Influence of Entrepreneurship on Economic Growth Ke LIU ${ }^{1, a,{ }^{*}}$, Meng-Han CHEN ${ }^{2, b}$
}

School of Economics and Management Zhengzhou University of Light Industry, Zhengzhou, 450002, China aliuke_liu@163.com, b114738673@qq.com

\begin{abstract}
Keywords: Entrepreneurship, Innovation, Economic growth.
\end{abstract}
\begin{abstract}
In recent years, people have realized that entrepreneurship plays an important role in economic growth. This paper first expounds the connotation of entrepreneurship by expounding the background of the current Chinese economy and a series of the literature review about entrepreneurship, then analyzes the impact of entrepreneurship on economic growth and discusses the shaping and cultivation of entrepreneurship. Finally, the article concludes that entrepreneurship and economic growth are positively correlated, and that entrepreneurship is crucial to the steady growth of China's economy. The innovation of this paper lies in improving the connotation of entrepreneurship and enriching the theoretical analysis of the impact of entrepreneurship on economic growth.
\end{abstract}

\section{Introduction}

At present, China's economy has entered a new normal. With the deepening of the overall reform, the new normalization of economic development mainly shows the following features: First, economic development is characterized by the medium-high rate of growth. Second, the economic structure is continuously optimized and upgraded. Third, innovation is the new driving force. Fourth, the challenge of economic development shows more new forms. In the coming period, the new normal of the Chinese economy will face new circumstances, new problems and new contradictions different from the past five years. The new economic and social environment has brought new opportunities and challenges for enterprises. Entrepreneurs play an important role in economic activities. From the allocation of various factors of production to the improvement and innovation of technology need the judgment, decision-making and organization of the entrepreneurs. Therefore, people regard entrepreneurs as the protagonists of the economic stage. The government takes the cultivation of entrepreneurship as an important measure to promote economic growth. Many studies at home and abroad show that entrepreneurship can promote economic growth. At the Third Plenary Session of the 18th CPC Central Committee, "making the market play a decisive role in the allocation of resources and giving better play to the role of government" is put forward and then the State Council make to build strategic deployment of "mass entrepreneurship and innovation", which shows that the essence of China's economic reform is the marketization. The core of marketization is to give full play to entrepreneurship. Entrepreneurship with innovation as the main content has become an indispensable factor in economic development. As the new normal continues to evolve and develop, the Chinese economy will further integrate itself into the wave of globalization in the world economy, which has played a certain role in promoting the formation of entrepreneurship. The Chinese economy is at a critical period of transformation and development. It is very important to make full use of the entrepreneurship to promote economic growth.

\section{Literature Review}

The study of contemporary entrepreneurship stems mainly from Joseph Alois Schumpeter, who believes that the essence of entrepreneurship lies in innovation and that the main driving force of innovation comes from entrepreneurship. In“ Economic Development Theory ”of Schumpeter (1912), economic development is described as an innovative process of creative destruction, and 
entrepreneurship plays a central role in promoting the process of economic[7]. At present, many scholars in academia have conducted extensive research on the relationship between entrepreneurship and economic growth. Abroad, McMillan \& Woodruff (2002) research on transition economies shows that the key to the success or failure of economic transformation lies in entrepreneurship[5]. Gries \& Naudé (2010) research on developed countries shows that the mode of economic growth is mainly the result of technological innovation and the recombination of factors of production supported by entrepreneurship[1]. Our country paid attention to this area lately, and the research results were relatively less. After Hong-Bin LI (2009) passed the empirical research, he believes that entrepreneurial entrepreneurship and innovative spirit have a significant positive impact on economic growth[2]. After analyzing the empirical research, Zong-Cheng YIN and Xiang-Jun LI (2012) found that economic growth was significantly influenced by entrepreneurship[8]. To sum up, the research on the relationship between entrepreneurship and economic growth in academia at home and abroad is continuously deepening, and to a certain extent, it has made useful theoretical and practical achievements.

\section{The Connotation of Entrepreneurship}

Entrepreneurship is a characteristic of entrepreneurial performance in production activities such as adventurism, decisive decision-making and supervision to motivate others, with emphasis on entrepreneurial adventurism. Entrepreneurs can achieve their predictable, bold and adventurous goals only through unconventional behavior. Therefore, the entrepreneurship and risk-taking are closely linked. The greater a person is to assume and tolerate risks, the more likely he is to start a business. The ability to perceive opportunities, innovations and profit-making is the core embodiment of entrepreneurship. The major connotation of entrepreneurship is innovation. Entrepreneurship is not directly involved in the production, but they use their market observation and innovation to dominate production. The essence of entrepreneurship is all focused on its subjective aspect. As the most active subject in the market economy, the ability of entrepreneurs to capture opportunities determines their ability to create and utilize markets, which is a unique feature of entrepreneurship. Entrepreneurship is reflected in its ability to adjust its behavior in a complex social setting. The subjective knowledge in entrepreneurship is represented by entrepreneurs' innovative consciousness, and the entrepreneurship innovation refers to the ideas and creativity different from others owned by entrepreneurs. The ultimate goal of entrepreneurship is to create profits. Creating profits is the most notable mark of subjective knowledge in the entrepreneurship. It is the label of entrepreneurship. Entrepreneurship can capture and develop opportunities for differences with others; the ultimate goal is to create profits.

\section{The Influence of Entrepreneurship on Economic Growth}

\section{Entrepreneurship Promotes Knowledge and Technological Progress}

In the enterprise innovation activities, the most significant aspect is the improvement of production technology. In a country's economy, the more entrepreneurs engaged in productive innovations, the more R \& D investment in technology, which will increase the role of technology in economic growth. Technological progress can raise labor productivity in an all-round way and change the mode of economic growth. There are two main approaches to entrepreneurship in promoting technological progress and utilization. On the one hand, an entrepreneurial individual carries the entrepreneurial knowledge by systematically learning the technical knowledge and directly enters the market to establish a business enterprise, thereby applying part of the technical knowledge to the society and realizing the overflow of technical knowledge. An important feature of knowledge spillover is the externality. New knowledge will be learned by other individuals and will be imitated and copied in large quantities, which will be rapidly popularized in society as a whole to promote economic growth. On the other hand, the subjective judgment of entrepreneurship dominates the development and application of science and technology. The core capital of entrepreneurs different 
from the average person lies in their perception of opportunity, realizing the opportunities in the market and guiding the direction of scientific research. By organizing the cooperation of relevant research institutes, entrepreneurs make their ideas implemented to the technical level and establish a direct link between technology and related markets, which fully demonstrates that entrepreneurship relies on subjective judgment to lead the development of technology and indirectly promotes the economic growth.

\section{Entrepreneurship Improves People's Livelihood}

Entrepreneurship will improve people's livelihood and promote social harmony. First of all, entrepreneurship can create new business opportunities and increase employment, thereby increasing residents' disposable income and household consumption level. Second, to gain some degree of government protection in the pursuit of higher commercial interests, entrepreneurs take the initiative to participate in some charitable activities as well as community governance and other activities and will take the initiative to provide some public goods to optimize the allocation of public resources. Third, entrepreneurs, while pursuing the maximization of their profits, have also brought fiscal revenue to the government, which in turn enhances the government's ability to improve public services. These behaviors indirectly promote economic growth.

\section{Entrepreneurship Promotes Reasonable Allocation of Resources}

Entrepreneurship is a necessary prerequisite for optimizing the allocation of resources. On the one hand, the optimal combination of resources is subject to the behavior of the market micro-entities. As one of the micro-entities, the behavior of enterprises is governed by entrepreneurs' thinking. Entrepreneurship is the soul and brain of an enterprise, and the production decisions made by an enterprise are made by entrepreneurs. The market can not leave human behavior to allocate resources. The real-time and dispersion of the market information determines that individual entrepreneurs can and should be the main dictators of resource allocation. Therefore, entrepreneurship plays an important role in the allocation of resources. On the other hand, entrepreneurial activities are subject to costs and risks. The fundamental requirement of their economic activities is to realize profits, and they need to make "economic calculations" from time to time. Therefore, entrepreneurship can avoid the phenomenon of resource consumption caused by the non-payment of income to the greatest extent. Finally, technological innovations have increased labor and capital productivity in some sectors, prompting entrepreneurs to optimize and integrate their production factors in pursuit of higher profits. In the process, the efficiency of resource allocation has been raised and further improved the level of economic development.

\section{Research on Shaping and Cultivation of Entrepreneurship}

\section{Comparison of Entrepreneurship among Chinese Regions}

Table 1. The development of new products and production in 2013 [6]

\begin{tabular}{|l|l|l|l|l|}
\hline Region & $\begin{array}{l}\text { New product } \\
\text { development }\end{array}$ & $\begin{array}{l}\text { New product } \\
\text { development }\end{array}$ & New product & \\
\cline { 2 - 5 } & $\begin{array}{l}\text { Number of } \\
\text { entry }\end{array}$ & $\begin{array}{l}\text { Expenditure } \\
\text { (ten thousand) }\end{array}$ & $\begin{array}{l}\text { Sales revenue } \\
\text { (ten thousand) }\end{array}$ & Export \\
\hline The whole nation & 358287 & 92467436 & 1284606903 & 228534683 \\
\hline Zhejiang Province & 47778 & 8216556 & 148820993 & 29813756 \\
\hline Yunnan Province & 1930 & 496845 & 4433810 & 208578 \\
\hline
\end{tabular}

The involvement of enterprises in the cooperation by production, study and research is a necessary condition for the success of technological innovation, while entrepreneurs are the drivers and undertakers to promote the industrialization of new technologies. The abundance of entrepreneurship in different regions of our country varies greatly, especially in the eastern and western regions. This section takes Zhejiang Province and Yunnan Province as examples to 
compare and analyze the difference of entrepreneurship abundance(see Table1). Based on the statistical yearbook of Yunnan Province and Zhejiang Province, this section uses entrepreneurship as a regulatory variable and explores the relationship between entrepreneurship and economic growth. From the data, entrepreneurship of Zhejiang is more abundant than Yunnan, which shows that Zhejiang Province is more capable of attracting entrepreneurs with entrepreneurship. The underdeveloped entrepreneur markets such as Yunnan are under-supplied, which has become a constraint on the social and economic development of these underdeveloped regions[4,6]. Therefore, it is an indispensable requirement to speed up the innovation of regional system, establish the concept of human capital of entrepreneur in the market economy and promote the operation mechanism of entrepreneur human capital as soon as possible.

\section{Cultivation of Entrepreneurship}

Under the background of the new normal, we must vigorously carry forward the entrepreneurship while at the same time providing an open environment for shaping an entrepreneurship that is in keeping with the characteristics of the time and making entrepreneurship a new growth pole of economic development. Faced with the new market environment, we need to cultivate and foster a large number of localized international entrepreneurs to meet the needs of the development of the times. The localization of entrepreneurship requires the following qualities:

(1) Outstanding breakthrough spirit. Only by constantly breaking through and surpassing the courage and spirit of ourselves can the enterprises be forever invincible and enable the enterprises to always maintain their core competitiveness. The breakthrough spirit of excellence requires that entrepreneurs have a good eye for discovery, be alert to see opportunities, be able to acutely see the crisis, and be able to continually break themselves and innovate themselves.

(2) Inexhaustible innovative thinking. Creative thinking is a creative thinking activity. Entrepreneurs need to create new technologies, new management models and organizational forms by finding new trends and discovering and using scattered knowledge and information effectively.

(3) A deep sense of responsibility. A deep sense of responsibility means that entrepreneurs should not only take all the consequences arising from the process of starting a business but also within the development of the enterprise, and also shoulder the social responsibility that the society expects from the enterprise. Entrepreneurs seek the necessary social welfare in the process of pursuing profits and pursue the corporate profits in the process of meeting the social needs, which are entrepreneurs who have a strong sense of social responsibility and are in keeping with the trend of the times.

(4) A far-sighted international perspective. With the promotion of the Chinese economy in global competitiveness, China has become more integrated into global trade. Many enterprises can directly participate in international competition in the closely-linked information age, which requires that outstanding entrepreneurs need an international vision and a far-sighted competitive landscape.

\section{Conclusion}

In the business operations, entrepreneurs play a role including innovation, entrepreneurship, management, coordination and risk-taking, of which innovation is the most basic. Therefore, entrepreneurship is an essential part of economic growth. To ensure the sustained and steady growth of China's economy, the cultivation of entrepreneurship is an effective way. In the dual context of the new economic normal and supply-side structural adjustment, entrepreneurship is of great significance for solving the insufficiency of our country's innovation and promoting economic growth. China's economy urgently needs to be transformed into a mode of economic growth dominated by entrepreneurship to further enhance total factor productivity and its contribution to the rate of economic growth and ultimately to shift the mode of economic growth[3]. China's economy is currently in a critical period of transformation and development. It is very important that we make full use of entrepreneurship to promote economic growth. 


\section{Reference}

[1] Gries T, Naudé W. Entrepreneurship and Structural Economic Transformation [J]. Small Business Economics, 2010, 34 (1): 13-29.

[2]Hong-Bin LI, Xing LI, Xian-Guo YAO. The Impact of Entrepreneurship and Innovation on China's Economic Growth [J]. Economic Research Journal, 2009, (10): 99-108.(In Chinese)

[3]Jin-Lei HAO, Xiang-Yang XING. Study on the impact of entrepreneurial innovation on Chinese economic growth [J]. Journal of Tianjin University of Commerce, 2017 (37)(In Chinese)

[4] Li-Yao LI. Transformation of the Entrepreneurship and economic growth patterns [D]. Zhejiang Gongshang University, 2017(In Chinese)

[5] McMillan J, Woodruff C. The Central Role of Entrepreneurs in Transition Economies [J]. The Journal of Economic Perspectives, 2002, 16 (3): 153-170.

[6]Ni-Na ZHANG, Zeng-Xiong YANG, Hong-Bo JIANG. Research on the Relationship between Entrepreneurship and Economic Growth [J]. China Market, 2016 (5)(In Chinese)

[7] Schumpeter, J. The Theory of Economic Development [M]. Harvard University Press, 1934.

[8] Zong-Cheng YIN, Xiang-Jun LI. Financial Development and Regional Economic Growth Based on the Perspective of Entrepreneurship [J]. Journal of Central University of Finance and Economics, 2012 (11)(In Chinese) 